\title{
The Analysis of Grammatical and Textual Equivalence Used in The Translation of Paolini's Novel of "Inheritance" into Indonesian
}

\author{
Badi'atul Azmina \\ State Institute for Islamic Studies (IAIN) Salatiga \\ Cow.az19@gmail.com
}

\begin{abstract}
This study examines kinds of grammatical and textual equivalence which are used by Poppy D. Chusfani in translating English into Indonesia language of Christopher Paolini's Novel of "Inheritance" as well as the most dominant equivalence used by Poppy D. Chusfani in translating English into Indonesia language of Christopher Paolini 's Novel of "Inheritance". This is descriptive qualitative research and the method of collecting data of this study are documentation and library research. The data in the novel which have been collected are classified into two kinds of equivalence; grammatical equivalence (number, gender, person, tense/aspect and voice) and textual equivalence (reference, substitution, ellipsis, conjunction and lexical cohesion). After analyzing and classifying the data, researcher discovered that there are 25 data of number, 27 data of gender, 38 data of person, 12 data of tense/aspect and 12 data of voice. Furthermore, researcher discovered that there are 33 data of reference, 9 data of substitution and ellipsis, 35 data of conjunction and 17 data of lexical cohesion. Those data presented are representative from all of the data in the novel, because the writer takes the data by its part among the translated sentences contained grammatical and textual (cohesion) equivalence. To sum up, the result shows that Poppy D. Chusfani uses all kinds of grammatical and textual (cohesion) equivalence, after all, grammatical equivalence of person is the most dominant data (38)
\end{abstract}


used by Poppy D. Chusfani in translating English into Indonesia language of Christopher Paolini's Novel of "Inheritance"

Keywords: Concept of Equivalence, Grammatical Equivalence, Textual Equivalence, Inheritance Novel

\begin{abstract}
Abstrak
Penelitian ini menelaah macam-macam padanan kata grammatikal dan tekstual yang digunakan oleh Poppy D. Chusfani dalam menerjemahkan Bahasa Inggris ke Indonesia dari Novel "Inheritance" karya Christopher Paolini begitu juga menelah padanan kata yang paling dominan digunakan. Penelitian ini merupakan deskriptif kualiatif dan metode pengumpulan datanya adalah dokumentasi dan studi pustaka. Data yang telah dikumpulkan dalam novel ini telah dikelompokkan berdasarkan dua macam padanan kata; grammatikal (nomor, jenis kelamin, orang, bentuk kata kerja dan kalimat pasif) dan tekstual (rujukan, penggantian, peniadaan, kata hubung dan kohesi leksikal). Setelah menganalisis dan menggolongkan data, peneliti menemukan bahwa ada 25 data nomor, 27 data jender, 38 data orang, 12 data bentuk kata kerja, dan 12 bentuk kalimat pasif. Di samping itu, peneliti juga menemukan 33 data rujukan, 9 data penggantian dan peniadaan, 35 data kata hubung, dan 17 data kohesi leksikal. Data yang disajikan tersebut mewakili semua data yang ada dalam novel karena peneliti mengambil data menurut bagian kalimat terjemahan yang mengandung padanan kata grammatikal dan tekstual. Kesimpulannya, hasil penelitian menunjukkan bahwa Poppy D. Chusfani menggunakan semua macam padanan kata grammatikal dan tekstual, namun padanan kata orang merupakan data yang paling dominan (38) yang digunakan dalam menerjemahkan Bahasa Inggris ke Indonesia dari Novel "Inheritance" karya Christopher Paolini.
\end{abstract}

Keywords: Konsep Padanan Kata, Padanan Gramatikal, Padanan Tekstual.

\title{
Introduction
}

This study examines how the concept of Grammatical and Textual Equivalence Used by Poppy D. Chusfani in Translating 
English into Indonesia Language of Christopher Paolini 's Novel of "Inheritance". The previous study are "An Analysis of Students' Ability in Translating Grammatical Equivalence" (e.g. Ruhansah, 2013), "The Question of Grammatical Equivalence in Translation" (e.g. Sudartini, n.d.) and "An Analysis of Technical Devices in Translation Procedures Applied by Listiana Srisanti in Translating A J.K. Rowling's Novel" (e.g. Lina, 2013). Few published studies focus on grammatical and textual equivalence in relation with novel translation.

This study aims to find and analyze the kinds of grammatical and textual equivalence which are used by Poppy D. Chusfani in translating English into Indonesia language of Christopher Paolini ‘s Novel of "Inheritance" as well as to find the most dominant equivalence used by Poppy D. Chusfani in translating English into Indonesia language of Christopher Paolini ‘s Novel of "Inheritance". This discussion gives additional information to the readers about analysis of grammatical and textual equivalence in translation of written language. Theoretically, the result of the research expected to inspire others to hold further research. Meanwhile, the result of the study will be useful for additional information in teaching translation concerning grammatical and textual equivalence practically.

\section{Understanding the world of Translation}

Translation is an activity of transferring meaning from the source language into the target language. Many experts give their definitions about translation. A deeper opinion was revealed by Brislin (1976:1, in Widiyantari 2012: 58) that "Translation is the general 
The Analysis of Grammatical and Textual Equivalence Used in The Translation of Paolini's Novel of "Inheritance" into Indonesian

term referring to the transfer of thoughts and ideas from one language (source) to another (target) whether the languages are in written or oral form". According to Brislin, translation is a general term that refers tothe transfer of idea or thought from the source language to the targetlanguage either written or spoken. Therefore the core of translation isthe transforming of message, meaning or idea from the source languageto the target one. Whereas, in the term of language style, both languagesused must be appropriate each other so that it will give the same effect between the reader of the source text and the reader of the translation version. That is because the resulted translation is accurate, understandable and acceptable.

Meanwhile, Catford (1974:20) stated that "Translation may be defined as the replacement of textual in one language (SL), by textual material in another language". In this definition, translator will only changethe text material or the passage in source language into the target language.Besides, in the real activity translator will not only transfer the substance material but he/she also has to consider the language style and the culture. Nida and Taber (1974:14) mentioned that "Translation consists ofreproducing in the receptor language and secondly in terms of style". It means that translation is the reexpression into target language from the source language, with first focus on the meaning expression and then the style of the expression as the second.

The mastery of the culture and both languages used is not a guarantee that someone can be a qualified translator. Many requirements have to be possessed. Bell (1991:36) said "The translator must, as acommunicator, possess the knowledge and skill." 
It means that a translator should have a wide deep insight and also skill. Furthermore, he has to master the translation theory and also has an understanding about the types of translation. Bell also revealed that “...the professional (technical)translator has access to five distinct kinds of knowledge: target language(TL) knowledge; text-type knowledge; source language (SL) knowledge;subject area ("Realworld") knowledge and contrastive knowledge." In doing the process of translation, a translator does not only transfer the meaning (Widiyantari, 2012: 57-59).

There are several aspects that should be taken into consideration such as the problems of non-equivalence. Baker (1992: 18) states that the choice of a suitable equivalent will always depend not only on the linguistic system or systems being handled by the translator, but also on the way both the writer of the source text and the procedure of the target text, i.e. the translator, choose to manipulate the linguistic systems in question.

The comparison of texts in different languages inevitably involves a theory of equivalence. Equivalence can be said to be the central issue in translation although its definition, relevance, and applicability within the field of translation theory have caused heated controversy, and many different theories of the concept of equivalence have been elaborated within this field in the past fifty years proposed by Leonardi (2000). Furthermore, Mona Baker in the book of In Other Words (1992) defines six types of equivalence: (1) equivalence at word level, (2) equivalence above the word level, (3) grammatical equivalence, (4) textual equivalence; thematic and word order, (5) textual equivalence; cohesion, and (6) pragmatic equivalence. 
However, Newmark states that knowledge of text-linguistics, in no way dispenses with the lexical, grammatical and referential problems that have to be solved at the particular and specific points of the text. The problems of coherence and cohesion coincide when the meanings of sentence joins are to be determined (1993: 4). For this reason, grammatical and textual (cohesion) equivalence are obviously important for translator to account for in the text. Consequently, the writer limits this study only on grammatical and textual (cohesion) equivalence.

Grammatical equivalence refers to the diversity of grammatical categories across languages. Baker (1992) notes that grammatical rules may vary across languages and this may pose some problems in the terms of finding a direct correspondence in the target language which later may induce the translator either to add or to omit information in the target language because of the lack of particular grammatical devices in the target language itself (p. 82). It includes:

\section{Number}

The idea of countability is probably universal in the sense that it is readily accessible to all human beings and is expressed in the lexical structure of all languages. However, not all languages have a grammatical category of number, and those that do not necessarily view countability in the same terms (Baker, 1992: 87).

\section{Gender}

Gender is a grammatical distinction according to which a noun or pronoun is classified as either masculine or feminine in some languages. The distinction applies to nouns which refer to 
animate beings as well as those which refer to inanimate objects (Baker, 1992: 90).

3. Person

The category of person relates to the notion of participant roles. In most languages, participant roles are systematically defined through a closed system of pronouns which may be organized along a variety of dimensions (Baker, 1992: 95).

4. Tense/Aspect

Tense and aspect are grammatical categories in a large number of languages. The form of the verb in languages which have these categories usually indicates two main types of information: time relations and aspectual differences (Baker, 1992: 98).

5. Voice

Voice is a grammatical category which defines the relationship between a verb and its subject (Baker, 1992: 102).

While textual equivalence refers to the equivalence in the terms of information and cohesion. It is up to the translator to decide whether or not to maintain the cohesive ties as well as the coherence of the source language (p. 132). It consists:

\section{Reference}

The term reference is traditionally used in semantics for the relationship which holds between a word and what it points to in the real world. The reference of chair would therefore be a particular chair that is being identified on a particular occasion (Baker 1992: 181). There are three types of reference: personal, 
The Analysis of Grammatical and Textual Equivalence Used in The Translation of Paolini's Novel of "Inheritance" into Indonesian

demonstrative and comparative reference (Halliday and Hasan 1976: 38-39).

\section{Substitution and ellipsis}

Unlike reference, substitution and ellipsis are grammatical rather than semantic relationships. In substitution, an item (or items) is replaced by another item (or items), while ellipsis involves the omission of an item. In other words, in ellipsis, an item is replaced by nothing (Baker, 1992: 186-187).

\section{Conjunction}

Conjunction involves the use of formal markers to relate sentences, clauses and paragraphs to each other (Baker 1992: 190).

\section{Lexical cohesion}

Lexical cohesion refers to the role played by the selection of vocabulary in organizing relations within a text (Baker, 1992: 202). Halliday and Hasan (1976) divide lexical cohesion into two main categories: reiteration and collocation. Reiteration, as the name suggests, involves repetition of lexical items. A reiterated item may be a repetition of an earlier item, a synonym or near synonym, a super ordinate, or a general word (Baker, 1992: 203). Collocation, as a subclass of lexical cohesion in Halliday and Hasan's model, covers any instance which involves a pair of lexical items that are associated with each other in the language in some way (Baker, 1992: 203).

In addition, text is the object of translation. The strategies of translation and how the translator translates language are seen in the target text. The writer chooses Inheritance, English novel written by 
Christopher Paolini for the reason that it is translated by Poppy D. Chusfani. She is a great editor, translator and writer (Hanifah, 2013: 1). She has certain strategies how to find the adequate equivalence from English into Indonesia language. The strategies includes how to translate conversion, 'he' or 'she', generic 'you', tenses, activepassive form and conjunction. For example, Poppy (2013: 14) says that some active sentences in English are easier to read if it is translated into passive in Indonesia. This type of translator's strategies and preference will cause problems of equivalence based on Mona Baker's theory of equivalence, including problems in grammatical and textual (cohesion) equivalence.

\section{Research Methodology}

\section{Research Method}

In this research, a qualitative descriptive method is used. Bogdan and Taylor (1972:5) define "qualitative method" as a kind of research that produces descriptive data as the result include theoretical review, people's common perspective and unique human's behavior. Deal with this concept, Kirk and Miller (1986:9) states that qualitative descriptive is a part of sociology whish depends on observation to human's language and human's attitudes fundamentally.

\section{Data source}

Sumanto states that data sources are divided into primary and secondary sources (Sumanto, 1995:11). Primary source is the 
The Analysis of Grammatical and Textual Equivalence Used in The Translation of Paolini“s Novel of "Inheritance" into Indonesian

research data obtained directly from the original source (no intermediaries) that are specifically collected by the researchers to address issues in research (Ruslan, 2004:31).It has relation with the object of the research. The primary resource is taking from English and Indonesia Novel of Inheritane by Christopher Paolini.

The writer conducted the research within one month namely in July $20^{\text {th }}$ until August $20^{\text {th }}, 2015$. Besides, she only takes the data from the novel until chapter 21 in both English and Indonesian novel because the novel consists of 80 chapters and more that 900 pages. For instance, she takes it started from page 1 until page 122 in English epub book version and it started from page 1 until page 209 in Indonesian book version. Those data presented are representative from all of the data in the novel, because the writer takes the data by its part among the translated sentences contained grammatical and textual (cohesion) equivalence.

\section{Technique of Data Collection}

In this research, the technique of data collection is documentation. Documentation may refer to the process of providing evidence (to document something or to the communicable material used to provide such documentation). In addition, the writer also uses library research or study of the library (Hadi, 1981:4). 


\section{Method of Data Analysis}

The writer defines analysis as consisting of three current flows activity: data reduction, data display and drawing conclusion/verifications (Miles and Hubberman, 1994: 10-12).

\section{a. Data Reduction}

Data reductionrefers to the process of selecting, focusing, simplifying, abstracting, and transforming the data that appear in written-up field or transcriptions. Data reduction is a form of analysis that sharpens sorts, focuses, discards, and organizes data in such a way that "final" conclusions can be drawn and verified. Qualitative data can be reduced and transformed in many ways: through selection, through summary or paraphrase, through being subsumed in a larger pattern, and so on.

b. Data Display

A display is an organized, compressed assembly of information that permits conclusion drawing and action. Designing a display-deciding on the rows and columns of a matrix for qualitative data and deciding which data, in which form, should be entered in the cells-are analytic activities.

c. Drawing Conclusion and Verifications

From the start of data collection, the qualitative analysis is beginning to decide what things mean-is noting regularities, patterns, explanations, possible configuration, casual flows and prepositions. Verification may be as brief as a fleeting second thought crossing the analyst's mind during 
writing, with a short excursion back to the field notes, or it may be thorough and elaborate, with lengthy argumentation and review among colleagues to develop "inter-subjective consensus" or with extensive efforts to replicate a finding in another data set. The meanings emerging from the data have to be tested for the plausibility, their sturdiness, their "confirmatibility"-that is, their validity.

\section{d. Data coding}

The writer marks the data by codes to make the analysis of each utterance easier. The data coding in this research is as follows:

Table 3.1 List of codes

\begin{tabular}{|l|l|}
\hline Abbreviation & Meaning \\
\hline SL & Source Language \\
\hline TL & Target Language \\
\hline ST & Source Text \\
\hline TT & Target Text \\
\hline Ch. & Chapter \\
\hline p. & Page \\
\hline Hal. & Halaman \\
\hline
\end{tabular}

\section{Discussion \& Research Finding}

After obtaining the data, the researcher found that Poppy uses all of the kinds of grammatical and textual (cohesion). For the 
grammatical equivalence, they are number, gender, person, tense/ aspect and voice. Likewise, for the textual equivalence (cohesion), they are reference, substitution and ellipsis, conjunction and lexical cohesion.

Here is the discussion based on the data collection:

Table 7. 1 Result of Grammatical Equivalence Analysis

\begin{tabular}{|c|c|c|c|c|}
\hline \multicolumn{5}{|c|}{ Grammatical Equivalence } \\
\hline Number & Gender & Person & $\begin{array}{l}\text { Tense/ } \\
\text { aspect }\end{array}$ & Voice \\
\hline $\begin{array}{l}\text { The most } \\
\text { dominant } \\
\text { number of } \\
\text { grammatical } \\
\text { category is } \\
\text { translating } \\
\text { plural into } \\
\text { plural form. } \\
\text { It is called } \\
\text { grammatical } \\
\text { ly } \\
\text { equivalence. }\end{array}$ & $\begin{array}{l}\text { The most } \\
\text { dominant } \\
\text { gender of } \\
\text { grammatic } \\
\text { al category } \\
\text { is } \\
\text { translating } \\
\text { masculine } \\
\text { into } \\
\text { neutral. It } \\
\text { is called } \\
\text { grammatic } \\
\text { ally non- } \\
\text { equivalenc } \\
\text { e }\end{array}$ & $\begin{array}{l}\text { The most } \\
\text { dominant } \\
\text { person of } \\
\text { grammatic } \\
\text { al category } \\
\text { is } \\
\text { translating } \\
\text { the data } \\
\text { grammatic } \\
\text { ally non- } \\
\text { equivalenc } \\
\text { e }\end{array}$ & $\begin{array}{l}\text { The most } \\
\text { dominant } \\
\text { tense/aspec } \\
\text { t of } \\
\text { grammatic } \\
\text { al category } \\
\text { is } \\
\text { translating } \\
\text { the data } \\
\text { grammatic } \\
\text { ally non- } \\
\text { equivalenc } \\
\text { e }\end{array}$ & $\begin{array}{l}\text { The most } \\
\text { dominant } \\
\text { voice of } \\
\text { grammatical } \\
\text { category is } \\
\text { translating } \\
\text { passive into } \\
\text { passive } \\
\text { form. It is } \\
\text { called } \\
\text { grammatical } \\
\text { ly } \\
\text { equivalence }\end{array}$ \\
\hline
\end{tabular}


The Analysis of Grammatical and Textual Equivalence Used in The Translation of Paolini“s Novel of "Inheritance" into Indonesian

\begin{tabular}{|l|l|l|l|l|}
\hline Total: 13 & Total: 8 & Total: 13 & Total: 9 & Total: 4 out \\
out of 25 & out of 27 & out of 38 & out of 13 & $\begin{array}{l}\text { of } 12 \text { data } \\
\text { data }\end{array}$ \\
data & data & $\begin{array}{l}\text { data } \\
\text { findings }\end{array}$ \\
\hline
\end{tabular}

As the data above, researcher discovers that there are 25 data of number and 13 of them are plural into plural form. For gender, there are 27 data and 8 of them are masculine into masculine form. Then, the researcher found 38 data of person and 13 of them are grammatically non-equivalence. Later, there are 12 data of tense/aspect and 9 of them are grammatically non-equivalence. The last, it is found 12 data of voice and 6 of them are passive into passive form.

Table 7.2 Result of Textual Equivalence Analysis

\begin{tabular}{|c|c|c|c|}
\hline \multicolumn{4}{|c|}{ Textual equivalence } \\
\hline Reference & $\begin{array}{l}\text { Substituion and } \\
\text { ellipsis }\end{array}$ & Conjunction & $\begin{array}{l}\text { Lexical } \\
\text { cohesion }\end{array}$ \\
\hline $\begin{array}{l}\text { The most } \\
\text { dominant } \\
\text { reference of } \\
\text { textual } \\
\text { (cohesion) } \\
\text { category is } \\
\text { personal }\end{array}$ & $\begin{array}{l}\text { The most } \\
\text { dominant } \\
\text { substitution and } \\
\text { ellipsis of } \\
\text { textual } \\
\text { (cohesion) } \\
\text { category is }\end{array}$ & $\begin{array}{l}\text { The most } \\
\text { dominant } \\
\text { conjunction of } \\
\text { textual } \\
\text { (cohesion) } \\
\text { category is } \\
\text { translating the }\end{array}$ & $\begin{array}{l}\text { The most } \\
\text { dominant } \\
\text { lexical } \\
\text { cohesion of } \\
\text { textual } \\
\text { (cohesion) } \\
\text { category is }\end{array}$ \\
\hline
\end{tabular}




\begin{tabular}{|l|l|l|l|}
\hline reference. & substitution. & $\begin{array}{l}\text { data textually } \\
\text { equivalence. }\end{array}$ & reiteration. \\
\hline $\begin{array}{l}\text { Total: } 16 \text { out } \\
\text { of 33 data } \\
\text { findings }\end{array}$ & Total: 6 out of 9 & $\begin{array}{l}\text { Total: } 25 \text { out } \\
\text { of } 35 \text { data } \\
\text { findings }\end{array}$ & $\begin{array}{l}\text { Total: } 10 \text { out } \\
\text { of } 17 \text { data } \\
\text { findings }\end{array}$ \\
\hline
\end{tabular}

Considering the data above, researcher discovers that there are 33 data of reference and 16 of them are personal reference. For substitution and ellipsis, there are 9 data and 6 of them are substitution. Next, there are 35 data of conjunction and 25 of them are textually equivalence. The last, there are 17 data of lexical cohesion and 10 of them are reiteration.

Then, the researcher found that the most dominant equivalence used by Poppy D. Chusfani is grammatical equivalence person. It shows 38 data. Those data presented are representative from grammatical and textual equivalence's data in the novel. The researcher does not involve all of it, because it will be more excessive. So, she only takes the representative part of the translated sentence to be presented.

\section{Conclusions}

The study shows that in translating the novel, Poppy D. Chusfani uses all the kinds of grammatical and textual equivalence. For grammatical equivalence, they are number, gender, person, tense/aspect and voice. For textual equivalence, they are reference, substitution and ellipsis, conjunction and lexical cohesion. Then, the 
The Analysis of Grammatical and Textual Equivalence Used in The Translation of Paolini's Novel of "Inheritance" into Indonesian

researcher concludes that the most dominant equivalence used by Poppy D. Chusfani is grammatical equivalence i.e. person. Most of the data are grammatically equivalence. All of those data presented are representative for all of the data in the novel, hence the researcher only took the sample of the sentences'part contain the grammatical and textual equivalence. 


\section{References}

Baker, Mona. 1992. In Other Words: A Coursebook on Translation. New York: Routledge.

Bell, Roger T. 1991. Translation and Translating: Theory and Practice. England: Longman.

Bogdan, R. and S. Taylor. 1972. Introduction to Research Methods. New York: Wiley.

BookBrowse. 2012. Christopher Paolini: Biography and Interview. RetrievedJune $7, \quad 2015$ from https://www.bookbrowse.com/biographies/index.cfm?author_nu $\underline{\text { mber }=934}$

Budianto, Langgeng \& Fardhani, Aan E. 2010.A Practical Guide for Translation Skill. Malang: UIN-Maliki Press.

Catford, J. C. 1965.A Linguistic Theory of Translation, London: Oxford University Press.

Chusfani, Poppy D. 2013. Menerjemahkan Novel Populer.Workshop Indonesian Readers Festival. Goodreads Indonesia.

DiYanni, Robert. 2004. Literatures: Approaches to Fiction, Poetry, and Drama. New York: McGraw-Hill Companies.

Donahue, Deirdre. 2011. 'Inheritance' by Christopher Paolini debuts at No. 1.USA Today. Retrieved June 7, 2015 from http://books.usatoday.com/bookbuzz/post/2011-11-

17/inheritance-by-christopher-paolini-debuts-at-no-1/567118/1

Encyclopedia of World Biography. 2003. Christopher Paolini Biography. Retrieved June 7, 2015 from http://www.notablebiographies.com/news/Ow-Sh/PaoliniChristopher.html

EnglishWell. 2013. Present perfect tenses table. Retrieved August 05, 2015 from

http://englishwell.biz/uploads/taginator/Sep2013/present_perfect tenses_table.jpg

FictionDB. 2005. Award-Winning Books by Christopher Paolini. Retrieved June 7, 2015 from http://www.fictiondb.com/author/christopher-paolini $\sim$ bookawards $\sim 36172 . \mathrm{htm}$ 
The Analysis of Grammatical and Textual Equivalence Used in The Translation of

Paolini's Novel of "Inheritance" into Indonesian

Finlay, N. F.. 1971. TeachYourself Books: Translating. Edinburg. The English Universities Press.

GuinnessWorldRecords. 2011. Youngest author of a bestselling book series. RetrievedJune $\quad 7, \quad 2015$ from http://www.guinnessworldrecords.com/world-records/youngestauthor-of-a-bestselling-book-series

Hadi, Sutrisno. 1981. Metodologi Research.Yogyakarta: FakultasEkonomi UGM.

Hanifah, Nida. 2013. Penulis Hebat di Indonesia. Retrieved August 20 , 2015 from https://nidahanifah277.wordpress.com/2013/02/02/penulishebat-di-indonesia/

Halliday, M. A. K. and Ruqaiya Hasan. 1976. Cohesion in Translation. London: Longman Group Ltd.

Halverston, Sandra. The Concept of Equivalence in Translation Studies: Much Ado About Something, in TARGET 9:2, TARGET, International Journal of Translation Studies, Vol 9:2, 1997, John Benjamins Publishing Company.

Hartono, Juni. 2015. Jenis-Jenis Kata Ganti Orang dan Kata Sapaan. Retrieved August 05, 2015 from http://2.bp.blogspot.com/CTjgYfVu8h0/VPGJVwOPW5I/AAA AAAAAAPY/nQDKsruTuU/s1600/11111.bmp

Holman, C. Hugh and William Harmon, eds. 2011.A Handbook to Literature. New York: MacMillan.

Hornby, A.S. 1987.Oxford Advanced Learner's Dictionary of Current English. New York: Oxford University Press.

House, Random. 2003. About the Author. Retrieved June 7, 2015 from http://www.alagaesia.com/author.php . 2007.Series Will Be Expanded to Include A Fourth Full-Length Novel.Retrieved June 7, 2015 from http://www.alagaesia.com/kvetha/paolini_announcement.pdf

Kecdraw. 2013. Summary of Inheritance Cycle. Retrieved June 7, 2015 from http://www.fanpop.com/clubs/inheritancecycle/articles/94763/title/summary-inheritance-cycle

Kirk, Jerome and Marc L. Miller. 1986. Reliability and Validity in Qualitative Research. USA: SAGE Publications Inc. 
Lina, Marisa Fran. 2013. An Analysis of Technical Devices in Translation Procedures Applied by Listiana Srisanti in Translating A J.K. Rowling's Novel. Salatiga: IAIN Salatiga.

Leonardi, Vanesa. 2000. Equivalence in Translation: Between Myth and Reality. TranslationTheory.Retrieved November 10, 2014 fromhttp://www.bokorlang.com/journal/14equiv.htm.

Macauley, Mike. 2011. Christopher Paolini Awarded Guinness World Record: Our Coverage of the Event Retrieved June 7, 2015 from http://www.shurtugal.com/2011/05/27/christopher-paolini-winsguinness-world-record-our-coverage-of-the-event/

Merriam Webster's Third New International Dictionary: Unabridged. 1981. USA: Encyclopedia of Britanica Inc.

Miles, Mattew B. and A. Michael Huberman. 1994. An Expanded Sourcebook Qualitative Data Analysis: Second Edition. USA: SAGE Publications.

Newmark, Peter. 1993. Paragraphs On Translation Topics in Translation; 1. England: Multilingual Matters Ltd.

Nida, Eugene A. \& Taber, Charles R. 1982.The Theory and Practice of Translation. Nedherlands: E.J. Brill.

Panou, Despoina. Equivalence in Translation Theories: A Critical Evaluation in Theory and Practice in Language Studies, Vol. 3, No. 1, pp. 1-6. January 2013. Finland: ACADEMY PUBLISHER.

Paolini, Christopher. 2011. Inheritance (epub file). USA: Random House Inc.

. 2012. FamousAuthors.org. Retrieved June 7, 2015 from http://www.famousauthors.org/christopher-paolini

. 2013. Inheritance. Jakarta: PT. Gramedia Pustaka Utama.

. 2014. Christopher Paolini Biography.Retrieved June 7, 2015 from http://www.paolini.net/biographies/christopher-paolini/

2015. Christopher: My Experience with Homeschooling. Retrieved June 7, 2015 from http://www.paolini.net/2015/05/29/christopher-my-experiencewith-homeschooling/ 
The Analysis of Grammatical and Textual Equivalence Used in The Translation of

Paolini's Novel of "Inheritance" into Indonesian

Quirk et al. 1972.A Grammar of Contemporary English. London: Longman Group Ltd.

Ramunè, Kasperavičienè. 2002. Contrastive Analysis of the Grammatical Category NUMBER in Nouns in the English and Lithuanian Languages in STUDIES ABOUT LANGUAGES, No. 2 May 2002. Lithuania.

Risdianto, Faizal. 2014. A handbook of English Literature. Yogyakarta: Javakarsa Media.

Ruhansah, Vina Inayati. 2013. An Analysis of Students' Ability in Translating Grammatical Equivalence (A Descriptive Study of the Sixth Semester English Department Students of State Institute for Islamic Studies (STAIN) Salatiga in the Academic Year of 2012/2013). Salatiga: IAIN Salatiga.

Ruslan, Rosadi. 2004. MetodePenelitian Public Relation danKomunikasi. Jakarta: Raja GravindoPersada.

Schmoop. 2003. Eragon Themes. Retrieved 21.29, June 7, 2015.

Sinclair, J. ed. (1995) Collins Cobuild English Grammar. Glasgow: Harper Collins Manufacturing.

Sudartini, Siti. . The Question of Grammatical Equivalence in Translation. Yogyakarta: Yogyakarta State University.

Sumanto.1995. Metodology Sosial dan Pendidikan.Yogyakarta: Andi Offset.

Trost, Dalice. 2012. Business Writing Tip \#23 - Be careful with your choice of pronouns. Retrieved August 05, 2015 from http://dalicetrost.com/writing-tip-23-684

Widiyantari, Yunita. 2010. The Strategy to Translate Metaphor. REGISTER.Vol. 5, No. 1, p. 57-59.

WritersServices. 2010. Success story: Christopher Paolini. Retrieved June 7, 2015 from http://www.writersservices.com/magazine/success-storychristopher-paolini

Yinhua, Xiang. Equivalence in Translation: Features and Necessity in International Journal of Humanities and Social Science, Vol 1 No. 10; August 2011. China. 